\title{
KETEGARAN KONSTRUKSI KATEK DAN VARIANNYA DALAM BAHASA MELAYU PALEMBANG
}

\author{
The Construction of Katek and its Variants in Palembang Malay Language
}

\author{
Houtman \\ Universitas PGRI Palembang \\ houtman03@yahoo.co.id
}

Naskah Diterima Tanggal 1 Juli 2018 —Direvisi Akhir Tanggal 12 November 2019—Disetujui Tanggal 12 Desember 2019 DOI: $10.26499 / \mathrm{rnh} . v 8 \mathrm{i} 2.863$

\begin{abstract}
Abstrak
Penelitian ini merupakan kajian morfosemantik yang melihat daya bentuk dan makna satuan lingual katek dan variannya, yaitu dak katek, katek idak, katek-katek, tek katek, dak katek-katek, dan dak katek idak, yang berasal dari bahasa Melayu Palembang. Kategori penelitian ini adalah kualitatif yang mendasarkan kajiannnya pada kesepadanan antara adaptasi linguistik, sosial, dan makna. Konsep kesepadanan diterapkan untuk melihat bentuk dan makna komunikasi pengguna bahasa tempatan, dalam hal ini adalah tindak tutur bahasa Palembang. Teknik yang digunakan dalam pengumpulan data adalah teknik catat dan wawancara. Dalam analisis data digunakan metode padan dengan teknik hubung banding menyamakan dan teknik hubung banding membedakan. Hasil penelitian menunjukkan bahwa bagi masyarakat Palembang, bentukan dak katek, katek idak, katek-katek, tek katek, dak katek-katek, dan dak katek idak yang berasal dari akar kata yang sama, yakni katek yang bermakna 'tidak ada' mengalami perkembangan dan penguatan makna sesuai dengan fenomena bahasa yang ada. Bentukan tersebut mengalami adaptasi makna berdasarkan laju perubahan sosial penggunanya.
\end{abstract}

Kata-kata Kunci: konstruksi katek, varian, bahasa Palembang, morfosemantik

\begin{abstract}
This research is a morphosemantic study that observes the power of form and meaning from katek lingual unit and its variants, i.e. dak katek, katek idak, katek-katek, tek-katek, dak katekkatek, and dak katek idak, that derived from Palembang-Malay language. This research category is qualitative, based its analysis upon the equivalences between adaptations of linguistic, social, and meaning. This equivalence concept is applied to notice the form and meaning of communication from local language users, in this case is Palembang language speech-act in their utterances. The technique used in collecting data is note taking and interview. The data analysis method used is analytical method, prevalently used in syncronical linguistics research. Data analysis used is method of equivalent with corresponding comparative linking technique and differentiating comparative linking technique. Research result showed that for Palembang people, the derivative of dak katek, katek idak, katek-katek, tek-katek, dak katek-katek, and dak katek idak which came from the same root, that is katek which means 'nothing', experienced development and reinforcement of meaning in accordance with the given language phenomenon. These derivatives experienced meaning adaptation based on the pace of the social changing of the users.
\end{abstract}

Keywords: katek constructions, Palembang language, morphosemantic 
How to Cite: Houtman. (2019). Ketegaran Konstruksi Katek dan Variannya Dalam Bahasa Melayu Palembang. Ranah: Jurnal Kajian Bahasa, 8 (2), 205-218. doi: https://doi.org/10.26499/rnh.v8i2.863

\section{PENDAHULUAN}

Bahasa merupakan fenomena komunikasi antarmanusia yang dapat mengalami perkembangan, pergeseran, dan perubahan makna. Hal itu dapat terjadi secara meluas, yakni apabila suatu bentuk kebahasaan mengalami berbagai penambahan makna yang keseluruhannya digunakan secara umum. Contohnya adalah kata menarik yang semula berkaitan dengan tali maknanya meluas sehingga dapat pula diartikan 'cantik', 'cakap', 'simpatik', 'menyenangkan', 'baik', dan 'menjadikan anggota'. Perubahan makna juga dapat terjadi secara menyempit apabila makna suatu kata memiliki spesifikasi atau pun spesialisasi. Kata guru, misalnya, pada mulanya dapat diartikan 'pembimbing rohani', atau 'pengajar silat' sehingga dikenal pula kata peguron yang akhirnya memiliki pengertian khusus 'pengajar di sekolah' sebagai salah satu bidang profesi. Makna kata juga dapat mengalami pergeseran akibat adanya sikap dan penilaian tertentu masyarakat pemakainya (Firdaus, 2011).

Konstruksi katek sebagai salah satu bentuk kebahasaan yang berasal dari bahasa daerah, dalam hal ini bahasa Melayu Palembang, juga dapat mengalami perkembangan, pergeseran, atau bahkan perubahan makna. Perkembangan, pergeseran, dan perubahan makna katek itu dapat terjadi secara (1) meluas, yakni katek yang semula hanya bermakna 'tidak ada', lalu mengalami perluasan menjadi 'tidak percaya', 'ragu-ragu', dan 'penolakan' serta (2) menyempit, yakni perubahan makna kata yang dapat terjadi karena pergeseran akibat adanya sikap dan penilaian tertentu masyarakat pemakainya. Contohnya adalah kata dak katek yang bermakna 'meninggal' pada kalimat Dio lah dak katek lagi di dunio ini ('Dia sudah tidak ada lagi di dunia ini').

Satuan lingual seperti katek biasanya berkaitan dengan pemaknaan yang diberikan. NISBET (2019) mengemukakan bahwa based on an analysis of the semantically-related verbs give, send, and put, it is claimed that prototypical, metaphorical and idiomatic expressions of a verb can all be licensed straightforwardly, but only if theory maintains separate syntactic and semantic representation of arguments in lexical entries, observing the 'parallel architecture', and only if argument tokens are licensed by the syntactic representation alone. Penjelasan itu dapat menjadi 
Ketegaran Konstruksi...

pemerkuat munculnya varian satuan lingual yang dapat berkembang dan dikembangkan secara linguistik dengan membawa maknanya sendiri.

Bahasa Palembang memiliki beberapa jenis cara penuturan yang seperti dalam bahasa Jawa disebut kromo dan ngoko. Di Palembang terdapat bahasa Palembang dengan penuturan halus, yaitu bebaso dan bahasa dengan penuturan kasar, yaitu bahasa Melayu Palembang yang lebih dikenal Palembang ari ari (Desmalinda dan Herdiansyah, 2016).

Bahasa Melayu Palembang, sebagai salah satu bahasa daerah yang bertumbuh dan berkembang di Sumatra Selatan, memiliki keragaman dan kekhasan kosakata dalam upaya mengungkap sebuah fenomena. Penggunaan kata katek yang bermakna 'tidak ada' merupakan kekhasan kosakata dalam bahasa Palembang yang digunakan dalam kehidupan sehari-hari oleh masyarakat Palembang. Hal itu dianggap lumrah dan biasa di kalangan masyarakat Palembang sehingga dalam percakapan sehari-hari pun ketika salah satu penutur mengucapkan kata katek, penutur lain akan memahami maksud si penutur. Konstruksi kata katek dalam bahasa Melayu Palembang juga dianggap unik ketika mengalami pengulangan, seperti katek-katek yang bermakna penolakan.

Penelitian terhadap bahasa Melayu Palembang juga telah banyak dilakukan. Sebut saja penelitian berjudul "Makna Pemakaian Bentuk -la dalam Bahasa Palembang” oleh Astuti (2015) dengan hasil penelitiannya adalah deskripsi makna bentuk -la dapat dikategorikan menjadi empat makna, yaitu bentuk -la sebagai makna umpatan, bentuk la sebagai makna pemberitahuan, bentuk -la sebagai makna perintah, dan bentuk -la sebagai makna penekanan. Ada pula penelitian berjudul "Penggunaan dan Makna Kata "Gawe" terhadap Kebiasaan Masyarakat Palembang” oleh Nadya (2018) dengan hasil penelitiannya adalah kata gawe ternyata dapat menjadi tiga belas variasi kalimat dan makna. Penelitian lainnya dilakukan oleh Desmalinda dan Herdiansyah (2016) dengan judul "Dampak Kehadiran Stasiun Televisi Berbahasa Lokal Pal Tv (Palembang Tv) pada Pelestarian Bahasa Lokal di Kota Palembang". Hasil penelitiannya adalah ada beberapa faktor yang menyebabkan kurang efektifnya pelestarian bahasa Palembang melalui media televisi, yakni (1) minat masyarakat terhadap tayangan televisi lokal cenderung masih kurang jika dibandingkan dengan televisi berjaringan nasional; (2) banyaknya penggunaan bahasa gaul yang berpengaruh pada penggunaan bahasa Palembang; dan (3) ketidaktahuan masyarakat berpendidikan menengah tentang adanya 
regulasi yang mendukung pelestarian bahasa dan budaya lokal sehingga sistem kontrol sosial terhadap media tidak berjalan secara maksimal. Selain itu, ada pula penelitian berjudul "Subtle Language of Palembang (Bebaso): Local Language Preservation of Extinction Through Preparing Dictionary" oleh Houtman (2016) dengan hasil penelitiannya adalah 1) Dictionary bebaso have been developed with a very decent categories based media expert assessment reaches $78.08 \%$ and $84.25 \%$ of matter expert; 2) Dictionaries bebaso effective development outcomes applied in SMA PGRI 2 Palembang to enhance students' understanding of the phenomenon of language. The positive response guardians of students against the use of dictionaries bebaso result of development reached 79.01\%. To be able to apply the dictionary bebaso teachers should have poured his creativity into the plot before it happened in the dictionary bebaso. Penelitian lainnya adalah "Leksikon Kekerabatan Etnik Melayu Palembang" oleh Muhidin (2017) dengan hasil penelitiannya adalah bahasan leksikon kekerabatan etnik Melayu Palembang dapat dikelompokkan menjadi dua, yakni leksikon kekerabatan dengan acuan konsanguinal dan acuan afinal. Konsanguinal mengacu pada leksikon yang menunjukkan adanya hubungan pertalian darah, sedangkan afinal mengacu pada hubungan yang disebabkan oleh pernikahan.

Dari beberapa penelitian yang telah disampaikan di atas tentang bahasa Melayu Palembang dapat disimpulkan bahwa penelitian bahasa Palembang cukup banyak diminati karena memiliki dua ragam bahasa: bahasa Palembang halus atau yang disebut dengan bebaso dan bahasa Palembang seari-ari (bahasa Melayu). Dalam laju perkembangan kosakatanya, dijumpai cukup banyak satuan kosakata yang memiliki keunikan dalam daya pakainya, misalnya kata katek, dak katek, dan dak katek-katek. Ketiga bentukan tersebut muncul dalam pelbagai situasi yang menyiratkan makna tertentu pula. Melalui tulisan ini akan dibahas pelbagai sudut penempatan ketiga satuan lingual tersebut dalam pokok kaji morfosemantik. Secara lebih tegas masalah yang akan dipaparkajikan dalam tulisan ini adalah sebagai berikut: 1) bagaimanakah bentuk morfosemantik pada satuan lingual dak katek, katek idak, katek-katek, tek katek, dak katek-katek, dan dak katek idak dalam bahasa Melayu Palembang? dan 2) Makna apa sajakah yang dihasilkan oleh proses morfosemantik pada satuan lingual dak katek, katek idak, katek-katek, tek katek, dak katek-katek, dan dak katek idak dalam bahasa Melayu Palembang? Tujuan pelaksanaan penelitian tersebut adalah untuk 1) mendeskripsikan 
Ketegaran Konstruksi...

bentuk morfosemantik satuan lingual dak katek, katek idak, katek-katek, tek katek, dak katek-katek, dan dak katek idak dalam bahasa Melayu Palembang dan 2) mendeskripsikan makna yang dihasilkan oleh proses morfosemantik satuan lingual dak katek, katek idak, katek-katek, tek katek, dak katek-katek, dan dak katek idak dalam bahasa Melayu Palembang.

Pemahaman tentang keunikan konstruksi katek saat muncul dalam pelbagai bentuk dan varian, yang kemudian menempatkan makna tertentu pula dalam bentukan barunya, akan menambah kekayaan khazanah bahasa daerah. Interpretasi makna baru atas bentukan tertentu yang merupakan hasil varian akan menambah nilai rasa bahasa. Rasa bahasa yang lahir dari hasil pengembangan suatu konstruksi bentukan bahasa merupakan cerminan bahwa bahasa terus tumbuh dan berkembang.

\section{LANDASAN TEORI}

Morfosemantik adalah analisis bahasa dengan mencari bentuk morfologis dan semantik (morfosemantik) kata atau istilah khusus dalam bahasa tertentu. Istilah merupakan bagian dari perbendaharaan kata dalam suatu bahasa, atau dapat diartikan pula sebagai kata atau gabungan kata yang mengungkapkan makna konsep, proses, keadaan, atau sifat yang khas dalam bidang tertentu, dan memberikan suatu pengertian.

Uhlenbeck (1982) mengemukakan bahwa analisis morfosemantik merupakan telaah kata untuk mencari makna kata dengan cara menguraikan morfem-morfem yang membentuk kata tersebut dengan menggunakan teori morfologi dan semantik. Morfosemantik dapat diartikan sebagai cabang ilmu linguistik yang mengidentifikasi satuan gramatikal beserta maknanya (Qorny, 2017). Dengan demikian, morfosemantik dapat dimaknai sebagai suatu kajian bahasa yang menggunakan gabungan teori morfologi dan semantik sehingga menghasilkan bentuk morfosemantik dan fungsinya.

Dalam penelitian ini akan ditunjukkan seberapa luas varian bentuk dan makna yang dihasilkan dari konstruksi katek ini. Konstruksi katek dalam kalimat saat kejadian itu, aku katek di rumah ('saat kejadian itu, saya tidak ada di rumah') bermakna 'tidak ada'. Fungsinya menunjukkan penolakan atas tuduhan yang diberikan kepadanya. Lain halnya dengan kalimat saat kejadian itu, aku dak katek di rumah. Keberadaan konstruksi dak katek adalah menguatkan penolakan atas kecurigaan seseorang terhadap 
dirinya. Dengan fungsi sebagai penegas, tampak bahwa penempatan konstruksi katek dalam kalimat tertentu membawa muatan makna yang berbeda.

\section{METODE PENELITIAN}

Metode penelitian ini menggunakan teori dari Mahsun (2011) tentang kesepadanan antara adaptasi linguistik, sosial, dan makna. Metode analisis data yang digunakan adalah metode analisis yang biasa digunakan dalam penelitian linguistik sinkronis. Untuk analisis data digunakan metode padan dengan teknik hubung banding menyamakan dan teknik hubung banding membedakan. Secara operasional, dalam penelitian ini metode dan teknik digunakan dengan maksud menghubungbandingkan antarbentuk-bentuk yang menjadi wujud makna tertentu dalam variasi bentuk bahasa yang digunakan oleh tiap-tiap penutur dalam situasi tertentu. Teknik hubung banding menyamakan dan teknik hubung banding membedakan adalah teknik yang digunakan untuk membandingkan konstruksi katek dengan cara mencari persamaan dan perbedaan dari segi bentuk dan makna dalam bahasa Melayu Palembang.

Teknik yang digunakan dalam pengumpulan data adalah teknik catat (Mahsun, 2011). Teknik catat ini digunakan agar hasil data yang diperoleh lebih akurat dan terorganisasi dengan baik karena dilakukan langsung di lapangan. Catatan lapangan berupa catatan deskriptif dan reflektif. Sumber data dalam penelitian ini adalah tuturan yang menggunakan kata katek yang digunakan dalam pelbagai situasi. Sumber data diperoleh dari kolom bahasa daerah di media massa cetak, semisal Sriwijaya Post atau dari tuturan langsung dalam dialog.

Penentuan data penelitian ini dilakukan dengan menggunakan teknik sampling purposive yang diperoleh dari hasil pengamatan. Prosedur analisis adalah sebagai berikut: 1) reduksi data yang meliputi pengidentifikasian, pengklasifikasian, dan pengkodean tuturan katek; 2) penganalisisan atas data ujaran yang memuat konstruksi katek; dan 3) verifikasi terhadap penafsiran data.

\section{PEMBAHASAN}

\section{A. Analisis Bentuk}

Bentukan 1: Katek ('tidak ada' sebagai makna dasar)

Deklaratif : Abaño katék di Rumah.

'Ayahnya tidak ada di rumah.'

Interogatif: Apo katék abaño di Rumah? 


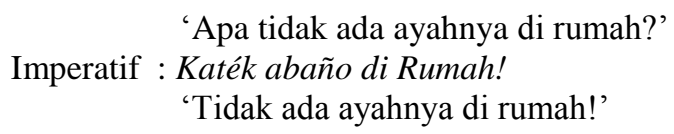

Bentuk dasar katek berterima untuk kategori yang ada. Kata katek tidak mengalami perubahan secara morfologis saat dilakukan perubahan susunan. Secara semantik, ketiga kategori pada kata katek yang bermakna 'tidak ada' juga tidak mengalami perubahan makna. Kenyataan itu menunjukkan bahwa katek dapat berdiri sendiri sebagai satuan linguistik.

\section{Bentukan 2: dak katek \\ Deklaratif : Abaño da? katék di Rumah. \\ 'Ayahnya tidak ada di rumah.' Interogatif: Apo da? katék abaño di Rumah? \\ 'Apa tidak ada ayahnya di rumah?' \\ Imperatif : Da? katék abaño di Rumah! \\ 'Tidak ada ayahnya di rumah!'}

Pada bentukan kedua, yakni dak katek, penempatan satuan lingual tersebut tidak membutuhkan adanya proses morfologis untuk dapat berterima sebagai satu rangkaian kebahasaan. Ketiga jenis wujud tuturan (kalimat berita, kalimat tanya, dan kalimat perintah (Martínez, 2013) dapat menerima penempatan dak katek sebagai wujud bahasa yang mampu menyesuaikan dengan barisan satuan lingual lainnya. Bentukan ini lebih dapat berterima dibandingkan dengan idak katek sebab terasa lebih luwes untuk dilafalkan. Namun demikian, dalam tataran tertentu bentukan idak katek terkadang masih diucapkan, misalnya sebagai penegasan sebuah jawaban. Perhatikan contoh berikut.
A: Ado motor dak?
B: katek!
A: Ado dak?
B: dak katek!
A: Payolah, ado dak?
B: Idak katek!

\section{Bentukan 3: katek idak}

Deklaratif : Abaño katé? ida? di Rumah.*)

'Ayahnya tidak ada di rumah'

Interogatif: Apo katék ida?abañodi Rumah?*)

'Apa tidak ada ayahnya di rumah?'

Imperatif : Katék idak abaño di Rumah!

'Tidak ada ayahnya di rumah!'

Bentukan katek idak memiliki keunikan untuk tertolak pada rangkaian linguistik yang berkaitan dengan satuan yang berdiri sendiri sebagai kalimat jenis deklaratif dan interogatif. Pada kategori imperatif, bentukan katek idak masih dimaklumkan untuk 
berterima pada tataran lisan, tetapi tingkat kelazimannya relatif rendah. Kebiasaan berbahasa yang menggunakan satuan ini untuk kategori imperatif mengakibatkan tataran kalimat ini dapat diterima. Sementara itu, secara morfosemantik, bentukan kata katek idak yang terdapat pada ketiga kategori di atas, yang asal kata tersebut adalah katek bermakna tidak ada, mengalami komposisi kata, tetapi tidak menimbulkan makna baru atau perubahan makna.

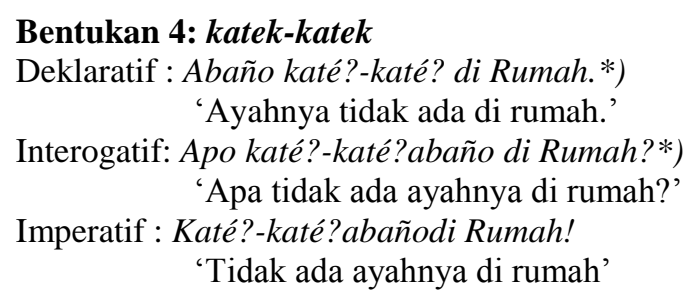

Pada bentukan yang keempat, katek-katek, keunikan muncul pada ketakberterimaan kalimat kategori deklaratif dan interogatif. Sementara itu, ketika bentukan katek-katek memanfaatkan teknik balik dengan posisi di awal kalimat, bentukan ini dapat berterima. Hal ini menunjukkan bahwa bentukan kata katek-katek memiliki keunikan dalam tuturan sehingga bentukan kata katek-katek hanya berterima pada jenis tuturan imperatif. Secara morfosemantik, bentukan kata katek-katek yang terdapat pada kalimat imperatif mengalami reduplikasi sehingga menimbulkan makna penolakan atau ketidakpercayaan terhadap suatu tuturan.

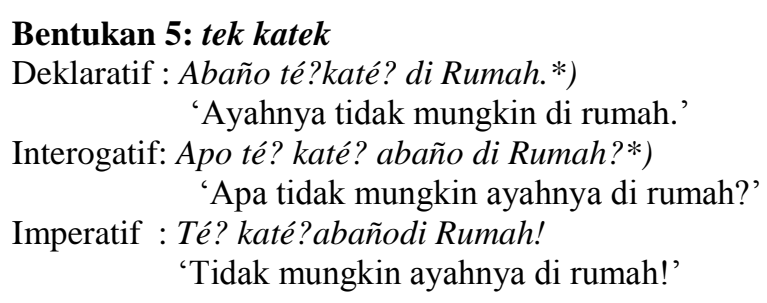

Ketegaran bentukan tek katek pada kategori deklaratif dan interogatif tidak dapat dipertahankan. Satuan lingual ini berterima saat dilakukan teknik balik yang menempatkan bentukan ini di awal kalimat. Pengulangan sebagian pada suku terakhir membuat bentukan varian katek menjadi menarik. Hal itu menunjukkan bahwa bentukan kata tek-katek memiliki keunikan dalam tuturan sehingga bentukan kata tekkatek hanya berterima pada jenis tuturan imperatif. Secara morfosemantik, bentukan kata katek-katek yang terdapat pada kalimat imperatif mengalami reduplikasi sekaligus abreviasi. Kata katek-katek merupakan reduplikasi dari kata katek yang bermakna tidak 
Ketegaran Konstruksi...

ada. Kemudian, kata katek-katek mengalami abreviasi menjadi kata tek-katek sehingga menimbulkan makna baru, yaitu 'ketidakpercayaan terhadap suatu tuturan'.

Bentukan 6: dak katek-katek

Deklaratif: Abaño da? kate?-kate? di Rumah.*)

'Ayahnya tidak mungkin di rumah.'

Interogatif: Apo da? kate?-kate?abañodi Rumah?*)

'Apa tidak mungkin ayahnya di rumah'

Imperatif : Da? kate?-kate?abaño di Rumah!

'Tidak mungkin ayahnya di rumah!'

Pada bentukan keenam, yakni dak katek-katek, satuan lingual ini cukup akrab bagi pengguna bahasa Melayu Palembang. Namun, memosisikannya dalam kategori deklaratif atau pun interogatif seperti pada contoh di atas masih belum berterima. Pelesapan suku pertama pada kata idak masih memberikan peluang pada satuan ini untuk berterima. Seperti pada contoh di atas satuan ini berterima pada saat berada pada awal kalimat. Hal itu menunjukkan bahwa bentukan kata dak katek-katek hanya berterima pada jenis tuturan imperatif. Secara morfosemantik, bentukan kata katekkatek yang terdapat pada kalimat imperatif mengalami tiga proses morfologis, yaitu 1) reduplikasi, dari kata katek menjadi katek-katek; 2) komposisi, dari kata katek-katek menjadi kata idak katek-katek; dan 3) abreviasi, dari kata idak katek-katek menjadi dak katek-katek. Tiga proses morfologis tersebut menimbulkan makna baru pada kata dak katek-katek yang bermakna ketidakpercayaan terhadap suatu tuturan.

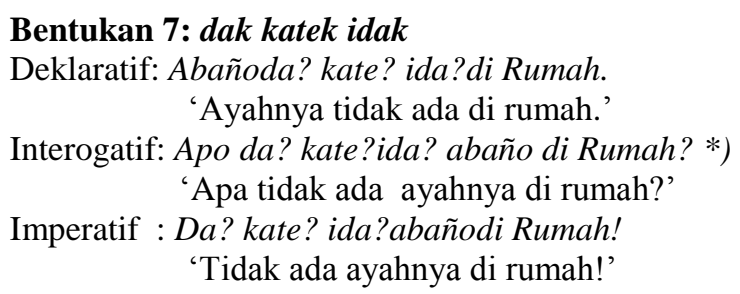

Dengan menempatkan dua kata penolakan dalam satu satuan lingual, bentukan dak katek idak cukup berterima untuk dua kategori kalimat, yakni deklaratif dan imperatif. Secara morfosemantik, bentukan kata dak katek idak yang terdapat pada kalimat deklaratif dan imperatif mengalami proses komposisi dari kata katek menjadi kata idak katek idak. Keberadaan kata idak setelah kata katek berfungsi sebagai penegas atas maksud yang disampaikan. 


\section{B. Analisis Makna}

Bentukan 1: katek

1.Penidakan: Abaño katék di Rumah.

'Ayahnya tidak ada di rumah.'

2.Kecurigaan: Apo katék abaño di Rumah?

'Apa tidak ada ayahnya di rumah?'

3.Penolakan: Ado duit dak? Kate?!

'Ada uang tidak? Tidak ada!'

4.Pembantahan: Katék abaño di Rumah!

'Tidak ada ayahnya di rumah!'

Variasi makna yang muncul dari contoh kalimat di atas setidaknya menunjukkan bahwa unsur katek memiliki peran dalam memberikan pesan tertentu: penidakan, kecurigaan, penolakan, dan pembantahan. Keberadaan intonasi turut menentukan sasaran makna yang diinginkan penutur. Hal itu terlihat pada contoh kalimat (1) kata katek pada kalimat 1 menggunakan intonasi datar yang menggambarkan tuturan dari kalimat deklaratif yang menyatakan tidak ada. Kalimat (2) merupakan bentuk kalimat deklaratif yang menggunakan intonasi naik bermakna kecurigaan terhadap suatu tuturan yang diucapkan penutur lain.

\section{Bentukan 2: dak katek}

1.Penguatan penidakan: Abaño da? katék di Rumah. 'Ayahnya tidak ada di rumah.'

2.Penguatan kecurigaan: Apo da? katék abaño di Rumah? 'Apa tidak ada ayahnya di rumah?'

3.Penguatan penolakan: Ado duit dak? Dak katek!

'Ada uang tidak? Tidak ada!'

4.Penguatan pembantahan: Da? katék abaño di Rumah!

'Tidak ada ayahnya di rumah!'

Makna yang dimunculkan pada bentukan kedua, yaitu kata dak katek, mengindikasikan penguatan dari bentukan pertama, yaitu kata katek. Penambahan kata dak yang disebut dengan komposisi kata tidak mengubah makna kata katek ('tidak ada'). Bahkan, kata tersebut telah berhasil mengeraskan makna yang dimaksudkan dalam tuturan tersebut. Penghilangan suku pertama pada kata idak telah memberi kenyamanan pelafalan sehingga bentukan ini berpeluang untuk berterima.

\section{Bentukan 3: katek idak}

1.Penguatan penidakan: Abañokaté? ida? di Rumah. 'Ayahnya tidak ada di rumah.'

2.Penguatan kecurigaan: Apo katék ida? abaño di Rumah? *) 'Apa tidak ada ayahnya di rumah?'

3.Penguatan penolakan: Abaño ado di Rumah kan? Yo dak? Kate? idak!*) 'Ayahnya tidak ada di rumah kan? Ya tidak? Tidak ada!

4.Penguatan pembantahan (meninggi): Katék idak abaño di Rumah! 'Tidak ada ayahnya di rumah!' 
Pada bentukan ketiga terlihat adanya tuturan yang tidak berterima. Pada contoh tersebut terlihat bahwa penempatan kata idak yang mengiringi kata katek telah membuat gugurnya keberterimaan makna penguatan kecurigaan dari kalimat (2) dan penguatan penolakan dari kalimat (3). Ketidakberterimaan ini membuat makna kata katek idak menjadi rancu ketika kalimat tersebut diucapkan. Sementara itu, pada kalimat (1) dan (4) terjadi penguatan maksud dari tuturan yang disampaikan. Penguatan ini terjadi lantaran pada dasarnya kata katek sudah bermakna 'tidak ada' yang kemudian dipertegas dengan penggunaan kata dak yang mengiringinya.

\section{Bentukan 4: katek-katek}

1.Makna kurang berterima: Abañokaté?-katé? di Rumah.*)

'Ayahnya tidak mungkin di rumah.'

2.Makna tidak berterima: Apo katé?-katé? abaño di Rumah?*)

'Apa tidak mungkin ayahnya di rumah?'

3.Penyangsian: Katé?-katé?abañodi Rumah!

'Tidak mungkin ayahnya di rumah'

Bentukan katek-katek pada contoh di atas hanya berterima pada kalimat (3) yang bermakna 'penyangsian'. Hal itu terjadi setelah terjadi dialog antara penutur dan mitra tutur yang merespons ketidaksetujuan atas pernyataan sebelumnya.

\section{Bentukan 5: tek katek}

1.Makna tidak berterima: Abaño té? katé? di Rumah.*)

'Ayahnya tidak ada di rumah'

2.Makna tidak berterima: Apo té? katé? abaño di Rumah?*)

'Apa tidak ada ayahnya di Rumah?'

3.Penegasan penolakan (penyangsian): Té? katé? abaño di Rumah!

'Tidak ada ayahnya di rumah'

Dalam bentukan kelima ini terjadi lagi pengulangan sebagian terhadap bentuk dasarnya. Ketika ditempatkan pada kategori kalimat tertentu, dalam hal ini deklaratif dan interogatif (seperti contoh di atas), ternyata tidak berterima. Hal itu disebabkan oleh kata tek katek yang bermakna menegaskan penolakan atau penyangsian terhadap suatu pernyataan. Dalam posisi sebagai perespons dari sebuah tuturan yang disampaikan oleh mitra tutur, kalimat (3) dapat berterima dengan makna penegasan penolakan atas sebuah pernyataan.

Bentukan 6: dak katek-katek

1.Makna kurang berterima: Abaño da? kate?-kate? di Rumah.*)

'Ayahnya tidak mungkin di rumah'

2.Makna tidak berterima: Apo da? kate?-kate?abañodi Rumah?*)

'Apa tidak mungkin ayahnya di rumah'

3.Penguatan penolakan (unsur keraguan): Da? kate?-kate?abaño di Rumah!

'Tidak mungkin ayahnya di rumah!' 
Penempatan bentukan dak katek-katek di awal kalimat seperti pada contoh di atas dapat berterima. Di dalam kalimat tersebut terkandung makna penguatan penolakan yang juga memuat unsur keraguan. Seyogianya kalimat (1) cukup berterima. Namun, bentukan ini jarang digunakan, utamanya dalam kalimat deklaratif. Pengulangan kata katek yang ternyata melemahkan kedudukan satuan lingual tersebut dipengaruhi oleh intonasi yang digunakan dalam suatu jenis kalimat.

Bentukan 7: dak katek idak

1.Penguatan penolakan: Abañoda? Kate? ida?di Rumah. 'Ayahnya tidak ada di rumah.'

2.Makna tidak berterima: Apo da? Kate?ida?abaño di Rumah? *)

'Apa tidak ada ayahnya di rumah?'

3.Penguatan penolakan: Da? Kate? ida? abañodi Rumah!

'Tidak ada ayahnya di rumah!'

Penggabungan dua kata penidakan di awal dan di akhir kata katek memancing keunikan tersendiri. Makna yang diusung berupa penguatan penolakan ternyata dapat berterima. Keunikan lain adalah pengulangan unsur penidakan tersebut ternyata hanya dilakukan sebagian dan ditempatkan sebelum kata katek. Makna kalimat pun menjadi semakin tegas untuk menyatakan ketidaksepakatan atas pernyataan awal yang disampaikan penutur terhadap mitra tutur yang memberi respons seperti tampak dalam kalimat (1) dan (3). Pada kalimat (1) dan (3) kata dak katek idak bukan bermakna mempertegas ketidaksepkatan, tetapi malah memperlihatkan kalimat tersebut menjadi rancu. Hal itu memperlihatkan bahwa bentukan variasi kata katek tidak dapat berterima pada beberapa jenis kalimat.

Secara keseluruhan terdapat keunikan pada kata katek yang digunakan oleh masyarakat Melayu Palembang. Konstruksi dalam kata katek terletak pada pemaknaan yang ganda atas satuan kata katek. Kemudian, pemunculan kata katek bergantung pada situasi bahasa yang ada. Satuan linguistik ini tidak peduli dengan makna asal dari satuan tersebut.

Untuk mempertegas paparan sebelumnya, berikut peneliti tampilkan dalam bentuk tabel. 
Tabel 1

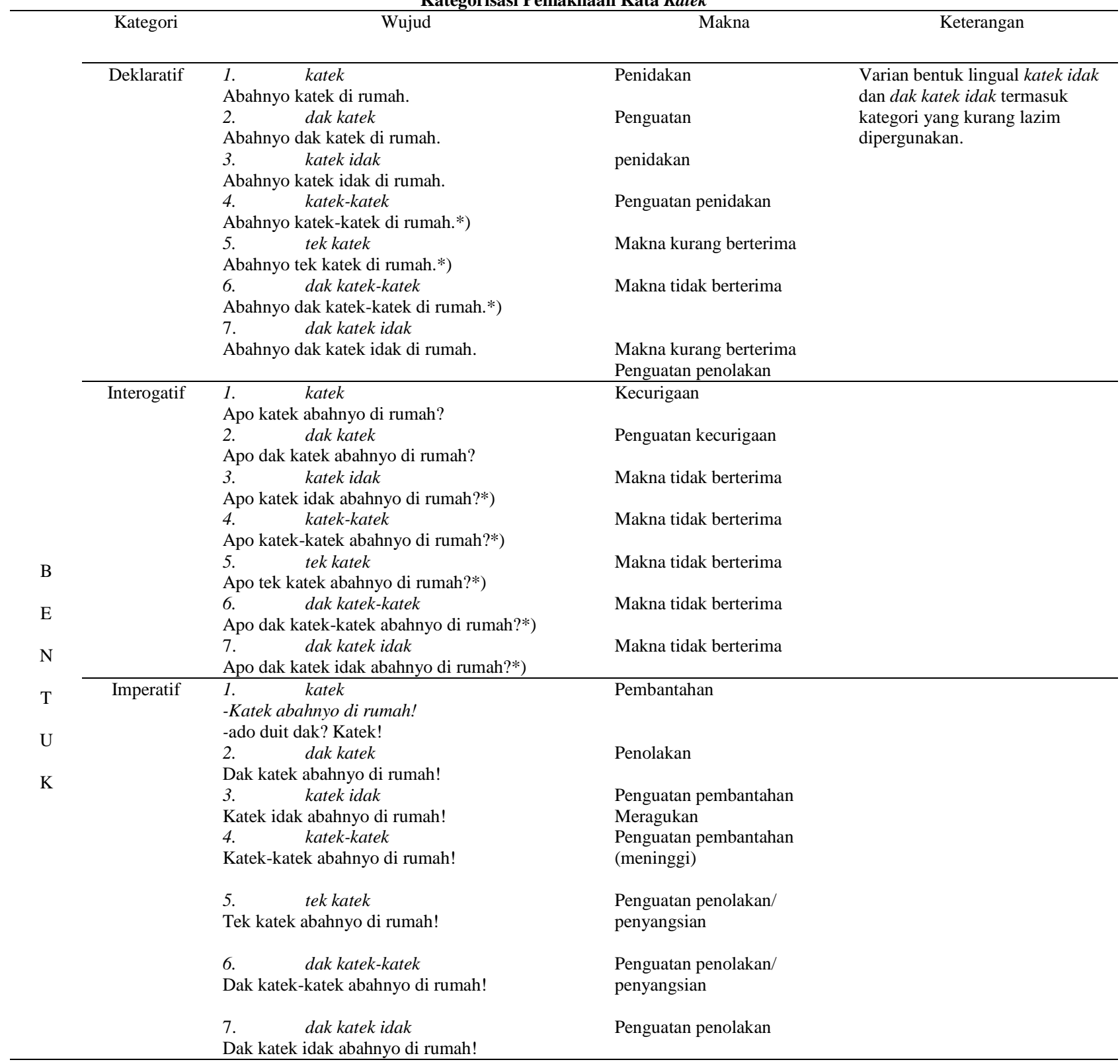

\section{PENUTUP}

Hasil paparan tentang keberadaan unsur katek dan variannya dalam pelbagai bentuk, telah memperkaya khazanah penggunaan satuan lingual bahasa Melayu Palembang. Pengusungan makna yang beragam juga membawa kekayaan interpretasi bagi penggunanya. Tumpang tindih makna menjadi menonjol saat masyarakat menganggapnya sebagai sebuah kebiasaan yang berterima. Pada hakikatnya telah terjadi ketidakmestian dalam penggunaan varian yang ada dalam kalimat. Namun, keramahan dalam menerima bentukan yang berkembang telah membuat munculnya varian yang 
unik. Itu merupakan sebuah kekayaan bahasa daerah yang tentu saja apabila dipadankan dengan bahasa yang serumpun, sangat dimungkinkan adanya silang pendapat tentang ketepatan penggunaan bentukan yang ada. Unsur katek dengan varian dak katek, katek idak, katek-katek, tek katek, dak katek-katek, dan dak katek idak telah menambah semarak kehidupan berbahasa daerah di Palembang.

\section{DAFTAR PUSTAKA}

Alwi, H. (2003). Tata Bahasa Baku Indonesia (3rd ed.). Jakarta: Balai Pustaka.

Astuti. (2015). "Makna Pemakaian Bentuk - La Dalam Bahasa Palembang". Kembara: Jurnal Keilmuan Bahasa, Sastra, dan Pengajarannya, 1(April), 26-33.

Cruse, A. (2004). Meaning and Language: An Introduction to Semantics and Pragmatics. Oxford: Oxford University Press.

Desmalinda, Herdiansyah, dan R. N. (2016). "Dampak Kehadiran Stasiun Televisi Berbahasa Lokal Pal Tv (Palembang Tv) pada Pelestarian Bahasa Lokal di Kota Palembang". Ranah, 5(2), 185-200. https://doi.org/10.26499/rnh.v5i2.153

Firdaus, W. (2011). "Kata-kata Serapan Bahasa Aceh dari Bahasa Arab: Analisis Morfofonemis". Jurnal Sosiohumaniora, 13, 223-234. DOI: https://doi.org/10.24198/sosiohumaniora.v13i2.5518

Grundy, P. (2000). Doing Pragmatics. Second Edition. New York: Oxford University Press.

Houtman, J. A. (2016). Subtle Language of Palembang ( Bebaso ): Local Language Preservation of Extinction Through Preparing Dictionary. 533-554.

Leech, G. (2014). The Pragmatics of Politeness. New York: Oxford University Press.

Mahsun. (2011). Metode Penelitian Bahasa: Tahapan Strategi, Metode, dan Tekniknya. Jakarta: Rajawali Press.

Martínez, N. D. C. (2013). Illocutionary constructions in English: Cognitive motivation and linguistic realization. New York: Peter Lang.

Muhidin, R. (2017). "Leksikon Kekerabatan Etnik Melayu Palembang". Ranah, 6(1970), 84-99.

Nadya, N. L. (2018). "Penggunaan dan Makna Kata "Gawe" terhadap Kebiasaan Masyarakat Palembang". PROSIDING SEMINAR NASIONAL 21 UNIVERSITAS PGRI PALEMBANG, 53(9), 1689-1699. DOI: https://doi.org/10.26499/rnh.v6i1.258

NISBET, T. (2019). "Meaning, metaphor, and argument structure". Journal of Linguistics, 1-34. https://doi.org/10.1017/s002222671900029x

Qorny, A. El. (2017). "Produktivitas Fi'l dalam Perubahan dan Pemaknaan (Analisis Morfosemantik terhadap Kamus Arab-Indonesia Karya Prof. DR. H. Mahmud Yunus". Lisanan Arabiya, I, 77-115.

Stenzel, A. (1996). "Development of Prepositional Case in a Bilingual Child". Linguistics: An Interdisciplinary Journal of the Language Sciences, (Online), 34, 1029-1058.

Uhlenbeck, E. M. (1982). Kajian Morfologi Bahasa Jawa. Jakarta: Djambatan.

Verhaar, J. W. M. (1996). Pengantar Linguistik. Yogyakarta: Gajah Mada University Press. 